unionists and engineers. Others joined tho team at different times to advise on seating, ventilation, position of controls and the muscular forces required to operate them. Among the problems was the lack of anthropometric data relating to bus drivers, so calculations had to be based on published measurements of National Service recruits. The need to increase the range of anthropometric data was stressed by other speakers, including Dr. J. S. Weiner, assistant director of the Medical Research Council's Unit on Climate and Working Ffficiency.

The discussion after the papers was in general lively, and there were many useful criticisms. The now familiar problem of communication was frequently mentioned as one of the reasons for the delay in applying biological research to industry. The biologists were advised that industry must not be led to expect that solutions to all its problems are within immediate grasp, and the industrialist was advised that research workers are not good salesmen, but that did not mean they did not have valuable services to offer.

There is, therefore, a strong probability that there will be a considerable demand from industry for biologists and biological advice. The difficulty will be in supply.

O. G. EDholm

\title{
ULTRACENTRIFUGATION OF BIOLOGICAL MACROMOLECULES
}

$\mathrm{T}$ HERE were about a hundred participants from several countries at the informal meeting on ultracentrifugation organized on behalf of the Faraday Society at Birmingham during September 14-15. Prof. K. O. Pedersen (Uppsala) gave a stimulating historical introduction. Papers by Dr. J. M. Creeth (Lister Institute, London) and Dr. H. G. Elias (Zurich) considered thermodynamical aspects of the sedimentation of multicomponent systems, while Dr. M. Gehatia (Frankfurt am Main) discussed various methods of evaluating $S$ and $D$ constants from the shape of the gradient curve of ultracentrifugation. Dr. G. A. Gilbert (Birmingham) described his theory concerning the analysis of moving boundaries in reversibly aggregating systems; examples of its application being provided in papers by Drs. S. N. Timasheff and R. Townend (Philadelphia) and by Mr. K. A. Cammack (Medical Research Establishment, Porton). A paper by Drs. A. J. Rowe and Dr. P. Johnson (Cambridge) considered the interaction of actin and myosin by ultracentrifugal studies.

Dr. P. A. Charlwood (Medical Research Council, Mill Hill) reviewed trends in the determination of molecular weights of macromolecules from transient state measurements in the ultracentrifuge and Dr. H. G. Elias (Zurich) discussed the various methods of determining the experimental values used in the Archibald expression. Dr. G. Träxler (Munich) con- sidered various ways of using the analytical ultracentrifuge in the measurement of diffusion constants of macromolecules. Papers on the sedimentation of charged macromolecules were presented by Prof. K. O. Pedersen and Dr. R. G. Wallis (Medical Research Establishment, Porton).

A new recording device for the ultra-violet absorption was discussed by Drs. J. B. Th'Aten and A. Schouten (Rijswijk, Netherlands), while Dr. I. Wiedmann (Basle) described a new schlieren optical system. Drs. P. A. Bianchi and K. V. Shooter (Chester Beatty Institute, London) considered the study of the sedimentation characteristics of deoxyribonucleic acid by the ultra-violet system.

Application of zone-centrifugation to the analysis of human serum proteins was described by Dr. D. R. Stanworth, Prof. J. R. Squire and Mr. K. James (Birmingham). Drs. P. Johnson and A. Albert discussed the sedimentation characteristics of human serum macroglobulins.

A suggestion by Prof. K. O. Pedersen that sedimentation coefficients should be referred to $25^{\circ} \mathrm{C}$. rather than $20^{\circ} \mathrm{C}$., as is becoming the practice in the United States, evolked considerable discussion, but no final decision was taken.

Prof. K. O. Pedersen, Dr. A. S. McFarlane (Medica] Research Council, Mill Hill) and Dr. R. A. Kekwick acted as chairmen and Dr. P. Johnson summed-up at the end of the proceedings. D. R. Stanworth

\section{MIGRATION OF MARINE ORGANISMS}

\begin{abstract}
A LATIN American symposium on migration of marine organisms was held at Guayaquil, Ecuador, from June 27 until July 1. It was organized jointly by the Unesco Science Co-operation Office for Latin America and the University of Guayaquil.

It was the fifth of the series of meetings on marine sciences which the Office has held since its foundation in 1949. The previous meetings had, like the Guayaquil one, the double character of symposium and working-party session. They were held at Concepcion, Chile in 1954; São Paulo, Brazil, in 1955; Montemar, Chile, in 1956; and Montevideo in 1957.

Dr. Enrique Rioja (Mexico) was electrid chairman of the symposium and Dr. Hugo Ferrando (Uruguay) acted as secretary. Thirteen marine scientists parti-
\end{abstract}

cipated, from the following countries: Argentina, Brazil, Chile, Cuba, Ecuador, Mexico, Peru, Uruguay. The Unesco Science Co-operation Office for Latin America was represented by Dr. Angel Establier.

The programme of the meeting was as follows: (1) migration of marine organisms, namely (a) fish, (b) invertebrates, $(c)$ cephalopods, $(d)$ birds, (e) other vertebrates; (2) study of environmental factors causing migration, $(a)$ oceanographic factors, $(b)$ biological factors; (3) standardization of methods for studying migratory phenomena, with the view of comparing results; (4) establishment of regional programmes for work on migration of aquatic popula. tions; (5) general discussion of other problems related to migration of marine urganisms. 